\title{
Risk factors and temporal trends for vascular access-related complications in coronary procedures: evolving from femoral to radial approach
}

\section{Factores de riesgo y variaciones temporales para complicaciones vasculares asociadas a procedimientos coronarios: evolución de la vía femoral a la radial}

\author{
Rodrigo Gopar-Nieto ${ }^{*}$, Fernando Huerta-Liceaga², Nancy L. Chávez-Gómez³, \\ Diego Araiza-Garaygordobil', Héctor E. Montes-Isunza4, Alejandro Cabello-López ${ }^{5}$, \\ Grecia I. M. Raymundo-Martínez' ${ }^{1}$ Gonzalo Carazo-Vargas ${ }^{1}$, and Arnoldo E. Loáisiga-Sáenz'
}

${ }^{1}$ Department of Cardiology, Instituto Nacional de Cardiología "Ignacio Chávez", Ministry of Health; ${ }^{2}$ Hemodynamics Service, Hospital Central Sur de Alta Especialidad PEMEX Picacho; ${ }^{3}$ Internal Medicine Service, Hospital Regional Licenciado Adolfo López Mateos; ${ }^{4}$ Cardiology Service, Centro Médico Nacional 20 de Noviembre, Instituto de Seguridad y Servicios Sociales de los Trabajadores del Estado (ISSSTE); ${ }^{5}$ Occupational Health Research Unit, Instituto Mexicano del Seguro Social, Mexico City, Mexico

\begin{abstract}
Introduction: Radial access is the gold standard for ST-elevation myocardial infarction; nevertheless, there is scarce information in Mexico. Objectives: The objectives of this study were to describe the differences in radiation exposure, intervention time, fluoroscopy time, complications and temporal trends, and risk factors among radial and femoral access for coronary procedures. Materials and Methods: $A$ total of 493 patients underwent coronary interventions by femoral or radial access. Sociodemographic and procedural data were recorded. A logistic regression model to determine risk factors for complications was performed. Results: The population included 346 men and 147 women, with a median age of 63 years, 159 underwent radial and 334 femoral approaches. Complications occurred in 18 patients (3.6\%), 11 in radial and 7 in femoral access, with a higher trend in the first 5 months $(n=14)$. Vasospasm was the most common $(n=9)$ complication. Median fluoroscopy time was 12 min for radial and 9 min for femoral groups, with a total radiation dose of $2282 \mu_{G m 2}$ and $2848 \mu_{G m 2}$, respectively. Temporal trends showed that complications occurred most frequently during the first 6 months of the study. The main predictors for complications were intervention time and one-vessel disease. Conclusions: Radial access had higher frequency of complications than femoral approach and they were more common during the first 6 months. The main risk factor was intervention time longer than $60 \mathrm{~min}$.
\end{abstract}

Key words: Cardiac catheterization. Radial artery. Femoral artery. Coronary angiography. Angioplasty. Mexico.

Correspondence:

${ }^{*}$ Rodrigo Gopar-Nieto

E-mail: rodrigogopar@gmail.com
Available online: 08-04-2019 Arch Cardiol Mex (Eng). 2019;89(4):273-279 www.archivoscardiologia.com 2604-7063/@ 2018 Instituto Nacional de Cardiología Ignacio Chávez. Published by Permanyer. This is an open access article under the CC BY-NC-ND license (http://creativecommons.org/licenses/by-nc-nd/4.0/). 


\section{Resumen}

Introducción: El abordaje radial es el de elección para infarto de miocardio con elevación del segmento ST, sin embargo se desconoce información en México. Objetivos: Describir las diferencias en exposición a radiación, tiempo de intervención, tiempo de fluoroscopía, complicaciones y sus variaciones temporales, además de los factores de riesgo entre el abordaje radial y el femoral para procedimientos coronarios. Método: Se incluyeron 493 pacientes que fueron sometidos a estudio angiográfico o intervenciones coronarias por abordaje radial o femoral. Se recabaron datos sociodemográficos, antecedentes y variables del procedimiento. Se realizó un modelo de regresión logística para determinar los factores asociados a complicaciones. Resultados: Se incluyeron 346 hombres y 147 mujeres, con mediana de edad de 63 años. A 159 se les realizó acceso radial y a 334 femoral. Las complicaciones ocurrieron en 18 pacientes (3.65\%): 11 en radial y 7 en femoral, teniendo mayor incidencia en los primeros 5 meses $(n=14)$ y siendo el vasoespasmo el más común $(n=9)$. La mediana de tiempo de fluoroscopía fue de 12 minutos para el radial y de 9 minutos para el femoral, con una dosis total de radiación de 2,282 $\mu_{G m 2}$ y 2,848 $\mu_{G m 2}$, respectivamente. Las tendencias temporales indicaron que las complicaciones fueron más frecuentes durante los primeros 6 meses. Los principales predictores fueron el tiempo de intervención y la enfermedad de 1 vaso. Conclusiones: $L a$ vía de acceso radial tuvo más complicaciones que la femoral. Se observaron más complicaciones en los primeros 6 meses del estudio. El principal predictor de complicaciones fue el tiempo de intervención mayor a 60 minutos.

Palabras clave: Cateterismo cardiaco. Arteria radial. Arteria femoral. Angiografía coronaria. Angioplastía. México.

\section{Introduction}

Radial access is the preferred puncture site for ST-segment elevation acute myocardial infarction (STEMI) treatment, due to lower complication rates such as bleeding, shorter hospitalization days, and similar success rates compared to femoral approach ${ }^{1-4}$. On the other hand, femoral access has several advantages including lower radiation exposure, more familiarity with this technique, more availability of devices, and higher procedural success rates, which have made this access the gold standard for many decades ${ }^{5,6}$. Nevertheless, controversies still exist regarding which vascular approach is better in diagnostic angiographic studies and non-ST-segment elevation myocardial infarction (NSTEMI). Therefore, the aim of this study was to compare the differences in intervention time, fluoroscopy time, frequency, temporal trends, and risk factors for complications, in both radial and femoral access in a third-level hospital in Mexico City.

\section{Materials and methods}

This was a cross-sectional study made in the Interventional Cardiology Service from the Hospital Central Sur de Alta Especialidad PEMEX Picacho in Mexico City during October 2009-January 2011. We included 493 patients in which coronary procedures were performed for stable coronary artery disease and acute coronary syndromes (both diagnostic and therapeutic). Before the interventional procedure, Allen's maneuver was performed in each patient to examine ulnar collateral flow. The choice of radial or femoral approach was left to the interventional cardiologist discretion. For radial approach with the Seldinger technique, puncture site was identified by palpation of the radial region $(2-3 \mathrm{~cm}$ proximal to the radial styloid process) and local anesthesia (2\% lidocaine, $10-15 \mathrm{ml}$ ) was applied to subcutaneous tissue. Puncture was done at $30-40^{\circ}$ and the needle was directed toward the flow direction. After obtaining flow, a guidewire was advanced and the needle was withdrawn. A dilator was later advanced through the guidewire and saline solution with heparin was injected. Finally, an introducer sheath was placed for the passage of guide wires or stents, as needed by each patient. For femoral approach with Seldinger technique, we identified the puncture site $2 \mathrm{~cm}$ below the inguinal ligament at the intersection between the anterosuperior iliac spine and the pubic symphysis. The same steps as for radial approach were later repeated. We recorded demographic variables such as age, weight, height, and hospitalization days from the medical history, as well as comorbidities such as hypertension, diabetes, chronic stable angina, previous myocardial infarction, hyperuricemia, dyslipidemia, and smoking. Angiographic procedural data such as type of vascular approach (radial or femoral), complications, intervention time, fluoroscopy time, amount of contrast media, dose-product area, and location of artery disease were taken from the interventional cardiology files.

\section{Statistical analysis}

Data were analyzed with STATA/IC v13 (StataCorp, College Station, Texas). For the descriptive analysis, binary variables were described as frequencies and 
Table 1. Population baseline characteristics

\begin{tabular}{|c|c|c|c|c|c|c|c|}
\hline Invariables & \multicolumn{2}{|c|}{$\begin{array}{c}\text { Overall }(n=491) \\
n(\%)\end{array}$} & \multicolumn{2}{|c|}{$\begin{array}{c}\text { Radial approach }(n=159), \\
n(\%)\end{array}$} & \multicolumn{2}{|c|}{$\begin{array}{l}\text { Femoral approach }(\mathrm{n}=334) \text {, } \\
\text { n (\%) }\end{array}$} & $\mathbf{p}$ \\
\hline Men & & $346(70.18)$ & & 131 (82.39) & & $215(64.37)$ & \multirow[t]{2}{*}{0.00} \\
\hline Women & & $147(29.82)$ & & $28(17.61)$ & & $119(35.63)$ & \\
\hline Hyperuricemia & & 196 (39.75) & & 58 (36.71) & & $138(41.82)$ & 0.28 \\
\hline CKD & & 87 (17.64) & & $36(22.78)$ & & $51(15.45)$ & 0.04 \\
\hline Previous MI & & $251(50.91)$ & & $79(50)$ & & $172(52.12)$ & 0.66 \\
\hline Dyslipidemia & & $245(49.69)$ & & $72(45.57)$ & & $173(52.42)$ & 0.15 \\
\hline Smoking & & $163(33.06)$ & & $59(37.34)$ & & $104(31.52)$ & 0.20 \\
\hline Hypertension & & $332(67.30)$ & & $107(67.72)$ & & $225(68.18)$ & 0.91 \\
\hline $\begin{array}{l}\text { Diabetes } \\
\text { mellitus }\end{array}$ & & $237(48.07)$ & & $74(46.84)$ & & $163(49.39)$ & 0.59 \\
\hline Stable angina & & $224(45.90)$ & & 71 (44.94) & & $153(46.36)$ & 0.76 \\
\hline ACS & & $89(18.24)$ & & $63(19.09)$ & & $28(20.14)$ & 0.48 \\
\hline Variables & $\mathbf{n}$ & $\begin{array}{c}\text { Median (IOR) } \\
\text { (minimum-maximum) }\end{array}$ & n & $\begin{array}{c}\text { Median (IOR) } \\
\text { (minimum-maximum) }\end{array}$ & n & $\begin{array}{c}\text { Median (IOR) } \\
\text { (minimum-maximum) }\end{array}$ & $\mathbf{p}$ \\
\hline Age (years) & 460 & $63(55-70)(23-88)$ & 128 & $62(54-69.5)(42-83)$ & 332 & $63(56-70)(23-88)$ & 0.35 \\
\hline Height $(\mathrm{cm})$ & 437 & 166 (160-170) (144-190) & 112 & $168(160-170)(144-185)$ & 325 & $165(158-170)(140-190)$ & 0.03 \\
\hline Weight (kg) & 438 & $77(69-83)(35-125)$ & 112 & $80(74-85)(51-125)$ & 326 & $75(66-82)(35-125)$ & 0.03 \\
\hline $\begin{array}{l}\text { Hospitalization } \\
\text { days }\end{array}$ & 488 & $5(4-8)(2-92)$ & 157 & $4(3-8)(2-68)$ & 331 & $5(4-8)(2-92)$ & 0.03 \\
\hline
\end{tabular}

CKD: chronic kidney disease; MI: myocardial infarction; ACS: acute coronary syndrome; IQR: interquartile range.

proportions, and they were analyzed with Pearson's independence test $\left(\chi^{2}\right)$ or Fisher's exact test, according to the number of individuals per case in the 2 by 2 table. Quantitative variables were analyzed first with Shapiro-Wilks normality test, and according to this, they were described as parametric (mean, standard deviation, and minimum-maximum) or non-parametric (median, interquartile range, and minimum-maximum). Bivariate analysis was done with Student's t-test for parametric variables, and with Mann-Whitney's U-test for non-parametric variables. We constructed a logistic regression model for determining the risk factors for complications. $p<0.05$ was considered statistically significant.

\section{Results}

We included 493 patients who underwent a percutaneous coronary intervention of diagnostic angiography, of which $70.18 \%$ were men and $29.82 \%$ were women, with a median age of 63 years, median height of $166 \mathrm{~cm}$, median weight of $77 \mathrm{~kg}$, and median of 5 hospitalization days (Table 1).

Regarding comorbidities, 50.91\% $(n=251)$ had previous myocardial infarction, $67.3 \%(n=332)$ hypertension, $48.07 \%(n=237)$ diabetes, $63.48 \%$ chronic stable angina, $49.69 \%$ dyslipidemia $(n=245), 39.7 \%(n=196)$ hyperuricemia, $17.64 \%(n=87)$ chronic kidney disease, and $33.06 \%(n=163)$ were smokers. The subgroup analysis showed significant differences between radial and femoral approach in sex, chronic kidney disease, hospitalization days, height, and weight (Table 1).

From the whole population, $30.08 \%$ did not have significant coronary disease or underwent diagnostic angiography for other reasons (i.e. congenital heart disease or valvulopathy); on the other hand, $36.17 \%$ had three-vessel disease. The most frequently diseased coronary artery was the left anterior descending, which was affected in $51.5 \%$ and $48.2 \%$ in the radial and femoral approach, respectively (Table 2).

The femoral vascular access was more commonly used in this study - 334 interventions. Complications 
Table 2. Description of coronary artery lesions by femoral or radial approach

\begin{tabular}{|l|c|c|c|}
\hline Variables & Radial approach $(\mathbf{n}=\mathbf{1 5 9})$ & Femoral approach $(\mathbf{n}=\mathbf{3 3 4})$ & $\mathbf{p}$ \\
\hline Normal coronary arteries & $28(20.14)$ & $71(23.28)$ & 0.46 \\
\hline 1-vessel disease & $33(23.74)$ & $52(17.05)$ & 0.09 \\
\hline 2-vessel disease & $26(18.78)$ & $55(18.03)$ & 0.86 \\
\hline 3-vessel disease & $52(37.41)$ & $126(41.31)$ & 0.43 \\
\hline Left anterior descending & $82(51.57)$ & $161(48.20)$ & 0.48 \\
\hline Circumflex artery & $68(42.77)$ & $130(38.92)$ & 0.41 \\
\hline Right coronary artery & $68(42.77)$ & $150(44.91)$ & 0.65 \\
\hline Left main coronary artery & $150(44.91)$ & $44(27.67)$ & 0.29 \\
\hline Intermediate artery & $31(19.50)$ & $60(17.96)$ & 0.68 \\
\hline Diagonal arteries & $43(27.04)$ & $96(28.74)$ & 0.69 \\
\hline Marginal arteries & $38(23.90)$ & $78(23.35)$ & 0.89 \\
\hline
\end{tabular}

Table 3. Overall complications, intervention times and radiation by femoral or radial approach

\begin{tabular}{|c|c|c|c|c|c|}
\hline Variables & \multicolumn{2}{|r|}{ Radial approach ( $n=159$ ) } & \multicolumn{2}{|c|}{ Femoral approach ( $\mathrm{n}=334$ ) } & $\mathbf{p}$ \\
\hline Complications & & $11(6.92)$ & \multicolumn{2}{|r|}{$7(2.10)$} & 0.00 \\
\hline Hematomas & & $3(1.89)$ & \multicolumn{2}{|r|}{$4(1.20)$} & 0.54 \\
\hline Vasospasm & & $8(5.03)$ & \multicolumn{2}{|r|}{$1(0.30)$} & 0.00 \\
\hline Ventricular fibrillation & & $0(0)$ & \multicolumn{2}{|r|}{$2(0.60)$} & 0.32 \\
\hline Death & & $0(0)$ & \multicolumn{2}{|r|}{$0(0)$} & 1 \\
\hline Crossover & & $9(5.66)$ & \multicolumn{2}{|r|}{$0(0)$} & 0.00 \\
\hline Variables & $\mathbf{n}$ & $\begin{array}{c}\text { Median (IOR) } \\
\text { (minimum-maximum) }\end{array}$ & n & $\begin{array}{c}\text { Median (IOR) } \\
\text { (minimum-maximum) }\end{array}$ & $\mathbf{p}$ \\
\hline Intervention time (hh: mm: ss) & 143 & 1:20:00 & 315 & 1:20:00 & 0.85 \\
\hline Fluoroscopy time (hh: mm: ss) & 143 & 00:12:00 & 315 & 00:09:01 & 0.05 \\
\hline Contrast media (ml) & 77 & $140(120-250)(80-700)$ & 124 & $122.5(100-180)(50-800)$ & 0.00 \\
\hline Dose-product area $\left(\mu \mathrm{G} \mathrm{m}^{2}\right)$ & 143 & $2282(1128.7-7290)(316.4-84,400)$ & 315 & $2800(1034-5600)(79-24,120)$ & 0.04 \\
\hline
\end{tabular}

IQR: interquartile range.

appeared 18 times, which represented $3.65 \%$ of the total population. The most frequent complication was vasospasm $(n=9)$, which occurred mainly in the radial approach, followed by hematoma $(n=7)$ : 3 in the radial and 4 in the femoral access. Crossover from radial to femoral approach happened in 9 times and was always associated to complications in the original puncture site.

Complications were significantly higher in the radial approach $-6.92 \%$ versus $2.1 \%$ in the femoral approach. Intervention time between both techniques was similar; nevertheless, fluoroscopy showed significant differences because the radial approach had 3 min more than the femoral. Finally, dose-area product was significantly higher in the femoral approach (Table 3).

In the logistic regression model, we found that intervention time longer than 60 min was associated with an increase in the overall occurrence of complications. Furthermore, we found certain tendencies toward risk increase for one-vessel disease, diagonal arteries disease, circumflex artery disease contrast media > $150 \mathrm{ml}$, dyslipidemia, left main artery disease, 
Table 4. Logistic regression model for complications in angiographies and percutaneous coronary interventions

\begin{tabular}{|c|c|c|c|c|}
\hline Variables & OR & SE & p & $95 \%$ CI \\
\hline 1-vessel disease & 6.19 & 7.69 & 0.14 & $0.54-70.76$ \\
\hline $\begin{array}{l}\text { Total intervention } \\
\text { time }>60 \mathrm{~min}\end{array}$ & 5.49 & 4.59 & 0.04 & $1.06-28.32$ \\
\hline Diagonal arteries & 3.93 & 3.25 & 0.09 & $0.77-19.89$ \\
\hline Circumflex artery disease & 3.80 & 3.22 & 0.11 & $0.72-19.98$ \\
\hline Dyslipidemia & 2.75 & 1.93 & 0.15 & $0.69-10.92$ \\
\hline Contrast media > $150 \mathrm{ml}$ & 1.62 & 1.41 & 0.57 & $0.29-8.94$ \\
\hline Left main artery disease & 1.54 & 1.49 & 0.65 & $0.23-10.28$ \\
\hline Fluoroscopy time $>10 \mathrm{~min}$ & 1.52 & 1.32 & 0.62 & $0.27-8.41$ \\
\hline Female sex & 1.28 & 0.91 & 0.72 & $0.31-5.22$ \\
\hline Smoking & 1.07 & 0.73 & 0.92 & $0.27-4.11$ \\
\hline 2-vessel disease & 1.00 & 1.54 & 0.99 & $0.04-20.60$ \\
\hline 3-vessel disease & 0.94 & 1.63 & 0.97 & $0.03-27.79$ \\
\hline $\begin{array}{l}\text { Right coronary artery } \\
\text { disease }\end{array}$ & 0.94 & 0.70 & 0.94 & $0.21-4.08$ \\
\hline $\begin{array}{l}\text { Previous myocardial } \\
\text { infarction }\end{array}$ & 0.91 & 0.56 & 0.87 & $0.26-3.10$ \\
\hline $\begin{array}{l}\text { Left anterior descending } \\
\text { disease }\end{array}$ & 0.80 & 0.58 & 0.76 & $0.19-3.30$ \\
\hline Age $<50$ years & 0.75 & 0.71 & 0.76 & $0.11-4.88$ \\
\hline Intermediate artery disease & 0.52 & 0.65 & 0.60 & $0.04-3.96$ \\
\hline Diabetes mellitus & 0.47 & 0.33 & 0.28 & $0.12-1.85$ \\
\hline Marginal arteries & 0.40 & 0.47 & 0.43 & $0.04-3.96$ \\
\hline Chronic kidney disease & 0.28 & 0.32 & 0.26 & $0.03-2.57$ \\
\hline Acute coronary syndrome & 0.22 & 0.27 & 0.22 & $0.01-2.46$ \\
\hline
\end{tabular}

$\mathrm{R}^{2}=0.3$. OR: odds ratio; $\mathrm{SE}$ : standard error; $95 \% \mathrm{Cl}$ : $95 \%$ confidence interval.

fluoroscopy > 10 min, female sex, and smoking, but without statistical significance (Table 4).

Temporal trends for the presence of complications showed that 14 events occurred in the first 6 months, and the $3^{\text {rd }}$ month had the largest amount of events $(n=5)$. Figure 1 shows the frequency of complications per month and a decreasing tendency of these events toward the end of the study.

\section{Discussion}

To the best of our knowledge, this is the first study to compare outcomes by either radial or femoral approach in a Mexican population. Campeau described radial access for the $1^{\text {st }}$ time in 1989 , and its use has been increasing since then ${ }^{1-6}$. The main anatomical advantages offered for coronary interventions are the absence of large-size nerves or veins near the puncture site and double circulation to the rest of the hand which prevents ischemia and movement complications. ${ }^{7}$ Furthermore, it has become the most used technique due to high success and low complication rates, along with bleeding reduction in the puncture site. Nowadays, due to a more extended use, the radial access is not only applied in coronary interventions, but in peripheral interventions such as carotid artery, femoral, superficial, mesenteric, and renal artery disease ${ }^{3}$.

Our study found that the complication rate was higher among radial access patients compared to femoral approach; nevertheless, we have to clearly state that most of these events $(n=14)$ occurred during the first 6 months of the implementation of this technique. This phenomenon can be explained by the learning curve period, which is inherent to every recently acquired technique, in which the center has to perform certain amount of procedures to gain experience to accomplish a high success rate and low complication frequency as explained in other studies ${ }^{8,9}$, On the other hand, it is important to recall that the study was made in an Interventional Cardiology Department that formerly was adapted to perform procedures using the femoral approach, and the operators had to adapt to the new radial-designed materials such as catheters, guide wires, and introducer sheaths.

As recently shown by the most recently published guidelines on ST-elevation myocardial infarction, radial approach has become the default access for coronary interventions in this context, due to its higher success, lower bleeding, and lower mortality rates ${ }^{1}$. It is important to recall that our study included acute coronary syndromes as well as diagnostic angiographies and procedures for chronic stable angina. Furthermore, it is important to mention the great amount of multivascular disease (i.e., disease of more than one vessel) to state a more complex coronary anatomy in this population, which increases the intervention and fluoroscopy times, as well as the overall complication rates including bleeding and vasospasm, and prolongs the intervention time as well as the fluoroscopy time.

Vascular complications are the most prevalent and are mainly provoked by anatomical variants in the puncture site ${ }^{10-12}$. After multiple punctures, radial artery tends to thicken its intimal media layer ${ }^{13}$; this generates higher complication and lower success rates. Unfortunately, we were not able to record which patients 


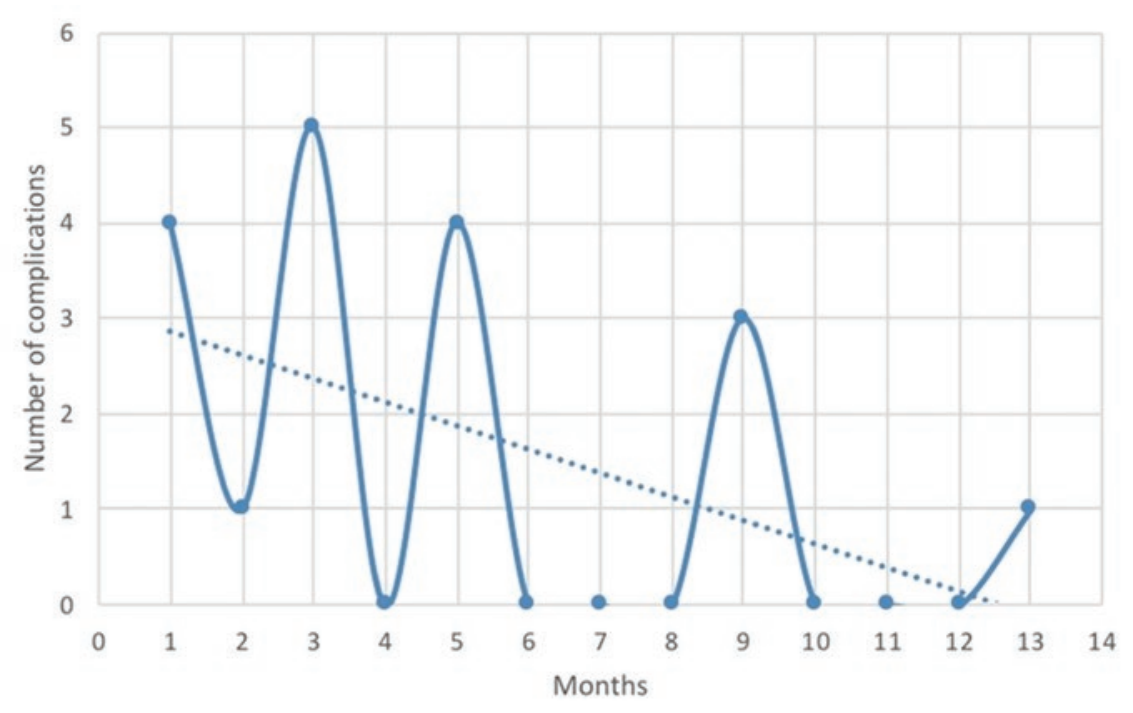

Figure 1. Temporal trends of complications in the femoral and radial approach.

underwent more than one puncture or have had a previous coronary intervention by the radial approach.

Vasospasm was the most commonly found complication in both types of approach. Meanwhile, crossover was done 9 times due to complication in the radial access. Radial access failure has been reported in up to $12.5 \%$, and the most common factors are the lack of guide wire support, difficulty to cannulate the vessel and unfavorable anatomy ${ }^{14}$.

In our analysis, women made up to almost $30 \%$ of the population, and the gender did not explain the presence of complications. Other studies have demonstrated that women are more prone to require more than one radial puncture and that they have a higher risk for bleeding compared to men, which can be explained due to a less prominent diameter of the radial artery ${ }^{15,16}$.

Radiation exposure is one of the main concerns for both the interventional cardiologist and the patient ${ }^{17}$. Radial access is associated to a higher radiation exposure, measured in $\mu \mathrm{G} \mathrm{m}^{2}$, in diagnostic and angioplasty procedures ${ }^{18,19}$; however, in our study, radiation exposure was higher in the femoral access, suggesting that radial access can be both safe and effective. Regarding interventional and fluoroscopy time, the previous studies showed longer exposure times in radial access ${ }^{20-23}$. This fact can be explained because many of these studies were performed before 2010, a time in which a lower frequency of radial procedures was performed. On the other hand, our study showed that there were differences in the fluoroscopy time, with lower times in the femoral approach; meanwhile, the logistic regression model that intervention times longer than 60 min was associated to more complications.

One of the most acclaimed advantages for the radial access is the reduction in hospitalization time due to a lower need of resting time and a faster time to the reintegration to the daily activities ${ }^{24}$. In our study, we were able to demonstrate a 1-day reduction in hospitalization, which can lower the costs of health systems and help to a faster reintegration to the patients' life.

Finally, we have to make emphasis that both approaches are safe and that randomized controlled trials show that in high-volume centers, in which a greater amount of procedures are made, radial access procedures have shown better results ${ }^{25}$.

The limitations of our study were the lack of randomization that could have made the groups more homogeneous, the high number of interventional cardiologist operators and being a single-center study.

\section{Conclusions}

This study showed that femoral approach had lower complication rates than the radial approach. Furthermore, the complications occurred more frequently in the first 6 months and the main predictor for complications was the intervention time $>60 \mathrm{~min}$. More studies are 
needed to identify earlier and prevent the potential complications associated to interventional procedures.

\section{Funding source}

None.

\section{Conflicts of interest}

The authors declare that they have no conflicts of interest.

\section{Ethical disclosures}

Protection of human and animal subjects. The authors declare that no experiments were performed on humans or animals for this study.

Confidentiality of data. The authors declare that they have followed the protocols of their work center on the publication of patient data.

Right to privacy and informed consent. The authors declare that no patient data appear in this article.

\section{REFERENCES}

1. Vranckx P, Frigoli E, Rothenbühler M, et al. Radial versus femoral access in patients with acute coronary syndromes with or without ST-segment elevation. Eur Heart J. 2017;38:1069-80.

2. Kiemeneij F, Laarman GJ, Odekerken D, Slagboom T, van der Wieken R. A randomized comparison of percutaneous transluminal coronary angioplasty by the radial, brachial and femoral approaches: the access study. J Am Coll Cardiol. 1997;29:1269-75.

3. Rao SV, Ou FS, Wang TY, et al. Trends in the prevalence and outcomes of radial and femoral approaches to percutaneous coronary intervention: a report from the national cardiovascular data registry. JACC CardiovasC Interv. 2008:1:379-86.

4. Bertrand OF, Rao SV, Pancholy S, et al. Transradial approach for coronary angiography and interventions: results of the first international transradial practice survey. JACC Cardiovasc Interv. 2010;3:1022-31.

5. Mann T, Cubeddu G, Bowen J, et al. Stenting in acute coronary syndromes: a comparison of radial versus femoral access sites. J Am Coll Cardiol. 1998;32:572-6.

6. Agostoni P, Biondi-Zoccai GG, de Benedictis ML, et al. Radial versus femoral approach for percutaneous coronary diagnostic and interventional procedures; Systematic overview and meta-analysis of randomized trials. J Am Coll Cardiol. 2004;44:349-56.

7. Campeau L. Percutaneous radial artery approach for coronary angiography. Cathet Cardiovasc Diagn. 1989;16:3-7.
8. Hess CN, Peterson ED, Neely ML, et al. The learning curve for transradial percutaneous coronary intervention among operators in the United States: a study from the national cardiovascular data registry. Circulation. 2014;129:2277-86.

9. Sciahbasi A, Romagnoli E, Trani C, et al. Evaluation of the "learning curve" for left and right radial approach during percutaneous coronary procedures. Am J Cardiol. 2011;108:185-8.

10. Greenwood MJ, Della-Siega AJ, Fretz EB, et al. Vascular communications of the hand in patients being considered for transradial coronary angiography: is the allen's test accurate? J Am Coll Cardiol. 2005;46:2013-7.

11. Yokoyama N, Takeshita S, Ochiai M, et al. Anatomic variations of the radial artery in patients undergoing transradial coronary intervention. Catheter Cardiovasc Interv. 2000;49:357-62.

12. Barbeau GR, Arsenault F, Dugas L, Simard S, Larivière MM. Evaluation of the ulnopalmar arterial arches with pulse oximetry and plethysmography: comparison with the Allen's test in 1010 patients. Am Heart J. 2004; 147:489-93.

13. Wakeyama $\mathrm{T}$, Ogawa $\mathrm{H}$, lida $\mathrm{H}$, et al. Intima-media thickening of the radial artery after transradial intervention. An intravascular ultrasound study. J Am Coll Cardiol. 2003;41:1109-14.

14. Cooper L, Banerjee S, Brilakis ES. Crossover from radial to femoral access during a challenging percutaneous coronary intervention can make the difference between success and failure. Cardiovasc Revasc Med. 2010;11:266.e5-8.

15. Ahmed B, Piper WD, Malenka D, et al. Significantly improved vascular complications among women undergoing percutaneous coronary intervention: a report from the Northern New England percutaneous coronary intervention registry. Circ Cardiovasc Interv. 2009;2:423-9.

16. Pristipino C, Pelliccia F, Granatelli A, et al. Comparison of access-related bleeding complications in women versus men undergoing percutaneous coronary catheterization using the radial versus femoral artery. Am J Cardiol. 2007;99:1216-21.

17. Bashore TM. Radiation safety in the cardiac catheterization laboratory. Am Heart J. 2004;147:375-8.

18. Mercuri M, Mehta S, Xie C, et al. Radial artery access as a predictor of increased radiation exposure during a diagnostic cardiac catheterization procedure. JACC Cardiovasc Interv. 2011;4:347-52.

19. Lange $\mathrm{HW}$, von Boetticher $\mathrm{H}$. Randomized comparison of operator radiation exposure during coronary angiography and intervention by radial or femoral approach. Catheter Cardiovasc Interv. 2006;67:12-6.

20. Geijer $\mathrm{H}$, Persliden J. Radiation exposure and patient experience during percutaneous coronary intervention using radial and femoral artery access. Eur Radiol. 2004;14:1674-80.

21. Brasselet C, Blanpain T, Tassan-Mangina S, et al. Comparison of operator radiation exposure with optimized radiation protection devices during coronary angiograms and ad hoc percutaneous coronary interventions by radial and femoral routes. Eur Heart J. 2008;29:63-70.

22. Neill J, Douglas H, Richardson $G$, et al. Comparison of radiation dose and the effect of operator experience in femoral and radial arterial access for coronary procedures. Am J Cardiol. 2010;106:936-40.

23. Lehmann R, Ehrlich JR, Weber V, et al. Implementation of the transradial approach for coronary procedures is not associated with an elevated complication rate and elevated radiation patient exposure. J Interv Cardiol. 2011;24:56-64.

24. Jabara R, Gadesam R, Pendyala L, et al. Ambulatory discharge after transradial coronary intervention: preliminary US single-center experience (Same-day transradial intervention and discharge evaluation, the STRIDE study). Am Heart J. 2008;156:1141-6.

25. Jolly SS, Yusuf S, Cairns J, et al. Radial versus femoral access for coronary angiography and intervention in patients with acute coronary syndromes (RIVAL): a randomised, parallel group, multicentre trial. Lancet. 2011;377:1409-20. 